\title{
Bioenergetics Potential of RR2 PRO Transgenic Soybean Subjected to Application of Herbicides Isolated and in Combination
}

\author{
Giovane Moreno ${ }^{1 *}$, Viviane Taisa Santos ${ }^{1}$, Leandro Paiola Albrecht ${ }^{1}$, Victor Salomão \\ Cesco $^{1}$ \\ ${ }^{1}$ Universidade Federal do Paraná, Campus Palotina, Palotina- Paraná, Brasil.
}

\begin{abstract}
In Brazil, there are several crops producing oil for biofuel production, such as canola, sunflower, peanut, cotton, castor bean, soybean, among others. There are parameters that indicate the energetic and economic viability for the production of biofuels, and that can be applied, for example, in transgenic soybeans. The present study aimed to evaluate the energetic viability of Intacta RR2 PROTM soybean for biofuel production.Experiments were conducted in the municipalities of Palotina and Marechal Cândido Rondon, both in the State of Paraná. Energy balance calculations were carried out from the production system, estimating energy expenditure, including the agricultural and industrial stages. The inputs used were considered as input of energy, while grain production, as output of energy. The energy balance of soybean biofuel showed positive values in the treatments with lower doses up to the recommended doses, highlighting the treatment glyphosate at 720 g.e.a. per hectare, which reached a positive energy balance (1: 1.11) for both municipalities. However, the Intacta RR2 PRO TM soybean was sensitive to treatments with high doses of glyphosate, which impaired productivity and consequently generated low economic returns.
\end{abstract}

Key words: Glycine max, bioenergy, biotechnology, energy generation, socioeconomic evaluation

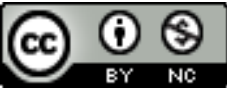

*Author of correspondence: moreno.giovane@gmail.com 


\section{INTRODUCTION}

The soybean complex has significant socioeconomic importance both in the world and in the national scenario, and for this sector to remain competitive in the globalized market, the rural producers constantly seek to increase productivity in order to obtain the highest possible profitability. To meet this goal, new and diversified technologies have been developed, ranging from the development of new fertilizers, agricultural pesticides, modern machinery and equipment, even cultivars adapted to different soil and climatic conditions and resistant to pests [5].

Among the main technologies launched, the biotechnology development represents an important tool to increase profitability, due to reductions in production costs by decreasing the application of pesticides/fertilizers that both increase productivity and reduce losses. In this context,a new generation of transgenic soybeans emerged, the RR2 PRO soybean, evolution of RR1transgenic soybean. The biotechnology present in RR2 PRO expresses genes that confer resistance to some insects of the order Lepidoptera and tolerance to glyphosate, in addition to conferring an increase in productivity [8]. Thus, this biotechnology is an important tool in the management of the main caterpillars that attack the crop and in the reduction of the use of pesticides, but the cost of adopting this biotechnology can raise the production costs.Therefore, for the producer to optimize the economic results, it is important to evaluate if the savings in the use of agrochemicals (for insects control) with the use of seeds with insect resistance compensates for the higher cost of the seeds where the price paid for the technology is incorporated, i.e. royalties [6].

The adoption of these technologies, together with the solid structure of the international market, the increase in the competitiveness of soybeans and consequently the increase in the consumption and volume of exports coupled with the growth of the world population and the concern with the environment makes soybean one of the major world crops both in the supply of vegetable protein and also in alternatives to renewable fuels, specially biodiesel. The numerous parameters to be analyzed include the energetic parameters of the production systems, which can be defined as an energy balance that allows the comparison analysis between different productivities. Thus, it is a tool that complements socioeconomic analysis [12]. In this sense, given the significance and great socioeconomic impact, the present study aimed to analyze the Intacta RR2 PROTM soybean under different treatments with herbicides isolated and in combination, and the economic and energetic viability in biofuel production.

\section{MATERIAL AND METHODS}

The data used in this study came from secondary sources. Data survey included a documentary analysis, based on the sources: EMBRAPA (Brazilian Agricultural Research Company), CONAB (National Supply Company) and ANP (National Petroleum Agency).

Experiments 1 and 2 were conducted in the municipalities of Palotina and Marechal Cândido Rondon, both in the State of Paraná. The municipality of Palotina is located in the West of the State, in which it is part of the western mesoregion of the State of Paraná and the microregion of Toledo. Its area is $647,284 \mathrm{~km}^{2}$, at the geographical coordinates $24^{\circ} 17^{\prime} 02^{\prime \prime}$ South latitude and 53'50'24" West longitude, at 333-meter altitude. Per capita income - GDP (R\$1.00) is 904.85 . The main branch of agricultural activity in the city is the cultivation of soybeans, with a total production of 160,200 tons, with an average yield of $3,269 \mathrm{~kg} \mathrm{ha}^{-1}$ in 2015 [13]. And the municipality of Marechal Cândido Rondon, also located in the West of the State, belonging to the western mesoregion of the State of Paraná and the micro region of Toledo. Its area is 
$748,281 \mathrm{~km}^{2}$, at 410-meter altitude, $24^{\circ} 33^{\prime} 22^{\prime \prime}$ South latitude and $54^{\circ} 03$ '24" West longitude. Per capita income - GDP (R\$ 1.00) is 1,036.38. It holds a total soybean production of 91,764 tons with an average yield of 3,170 $\mathrm{kg} \mathrm{ha}^{-1}$, in 2015 [13].

In the municipality of Palotina, the soil of the experimental area has $\mathrm{pH}\left(\mathrm{CaCl}_{2}\right)$ of 5.50 , base saturation of $58.16 \%$, aluminum saturation of $0 \%, \mathrm{P}$ and $\mathrm{S}$ levels of 44.27 and $5.17 \mathrm{mg} . \mathrm{dm}^{-3}$, respectively. For $\mathrm{H}^{+} \mathrm{Al}^{3+}, \mathrm{Ca}, \mathrm{Mg}, \mathrm{K}$ and $\mathrm{CEC}$, values were 2.95, 3.14, 0.80, 0.16 and 7.05 Cmolc. $\mathrm{dm}^{-3}$, respectively. In the municipality of Marechal Cândido Rondon, the soil of the experimental area has $\mathrm{pH}\left(\mathrm{CaCl}_{2}\right)$ of 5.6, aluminum saturation of $0 \%$, basesaturation of $76 \%$ and levels of $\mathrm{P}$ and $\mathrm{S}$ of 31.61 and 7.52 mg.dm ${ }^{-3}$, respectively; and $\mathrm{H}^{+} \mathrm{Al}^{3+}, \mathrm{Ca}, \mathrm{Mg}, \mathrm{CEC}$ and $\mathrm{K}$ of 3.02, 9.44, 3.09 and 17.97 Cmolc. $\mathrm{dm}^{-3}$, respectively.

The crop management followed the agronomic recommendations for the region and the plots were kept free of weeds. Therefore, we did not evaluate the control of weeds, but the selectivity of the treatments with herbicides in the transgenic event under study.

The experiments were conducted in a randomized complete block design with four replicates. The statistical analysis of the productivity data was performed following univariate procedures, with application of analysisof variance, Tukey's test for qualitative treatments and regression analysis for quantitative treatments, at 5\% probability.

Experiment 1 consisted of the use of Glyphosate isolated and in combination with other herbicides used at maximum doses recommended in the package insert (Control: 0; Glyphosate: 1440; Glyphosate + Clethodim: 1440 + 108; Glyphosate + Cloransulam-Methyl: $1440+40$; Glyphosate + Chlorimuron-Ethyl: $1440+17.5$; Glyphosate + Lactofen: $1440+180$; Glyphosate + Fluazifop-p-butyl: $1440+187.5$ )

In experiment 2, Glyphosate was applied in increasing doses: $0 ; 720 ; 1440 ; 2160$; 2880; 3600 and 4320 grams of acid equivalent (g.a.e.) per hectare, both experiments with control and six treatments.

These experiments were carried out in the 2013/2014 crop season, with the cultivar Monsoy 6210: Intacta RR2 IPROTM. The experiments were conducted in a randomized complete block design with four replicates.

The method used to convert the soybean yield into biodiesel $\left(\mathrm{Kg} \mathrm{ha}^{-1}\right)$ is based on the following data: oil content in soybeans is, on average, $18 \%$ soybean oil $(0.18 \mathrm{~kg}$ soybean oil), and the literature presents this average oil content in grains. And it is necessary $0.90 \mathrm{~kg}$ soybean oil to obtain one liter of soybean biodiesel. [10], [9]

For a biofuel derived from some source to be considerable in a bioenergy program, the energy balance must be greater than one [6]. The statistical analysis of the productivity data was done following univariate procedures, with analysis of variance, Tukey's average test for qualitative treatments.

Cavalcante et al. [7] reported a variation in soybean oil content between $18.56 \%$ and $24.03 \%$, in addition to observing that as the protein content increases, the oil is reduced. Albrecht et. al [2] demonstrated that when herbicides are used in soybeans, depending on the type of herbicide, the season and the stage in which they are applied, the oil contents may vary. Therefore, the present study used the average of $18 \%$ soybean oil.

In the formation of biodiesel characteristics, ANP-RANP 07/08 establishes a range of density values between 850 and $900 \mathrm{~kg} \mathrm{~m}^{-3}$ [1].

From this assumption, to obtain biodiesel per liters $\left(\mathrm{L} \mathrm{ha}^{-1}\right)$, it was necessary to convert the biodiesel per $\mathrm{kg}\left(\mathrm{kg} \mathrm{ha}^{-1}\right)$, based on the soybean biodiesel density of 0.88 $\mathrm{kg} \mathrm{m}^{-3}$ (ha), the determination of the value of the biodiesel density is within the range established by ANP [1]). For conversion, the following formula was used:

$\mathrm{d}=\mathrm{m} / \mathrm{v}$

Where: $\mathrm{d}=$ density, $\mathrm{m}=$ mass, $\mathrm{v}=$ volume 
In order to establish the energy balance of biodiesel, the study was divided into three stages: energy inputs and outputs in soybean production (agricultural); energy input for industrial production; and energy outputs from the production system. For each stage, we considered their respective activities. Inputs and outputs of energy in soybean production: manpower, machinery, fuel, fertilizers, seeds, transportation and agricultural pesticides. Energy input for industrial production: electricity, steam, water, heat, losses, stainless steel and cement. And in the last stage, energy outputs from the production system: hulls, oil and meal.

No-till system was assumed and the calculations considered the energy expenditure at pre-sowing, sowing, management, harvesting and transportation in the production and industrial stages [11].

According to Pimentel and Patzek [14], the expenditure of 6.3 hours of manpower ha${ }^{1}$ for the no-till system was adopted. The use of $2,000 \mathrm{~kg} \mathrm{ha}^{-1}$ limestone was used, with the expenditure of 66 liters of diesel ha- ${ }^{-1}$. And for transportation (machinery, fuel, seeds and production flow), the average distances of crops to input distribution and harvesting were considered, with an average value of $154 \mathrm{~km}$.

Broch and Ranno [4] considered that every $1,000 \mathrm{~kg}$ of soybean requires $20 \mathrm{~kg} \mathrm{P}_{2} \mathrm{O}_{5}$ and $20 \mathrm{~kg} \mathrm{~K}_{2} \mathrm{O}$, and in relation to Boron, $1 \mathrm{~kg} \mathrm{ha}^{-1}$ was adopted, considered to be an ideal value to eliminate micro element deficiencies in sensitive cultivars.

For the calculation of soybean seeds, it was considered the formula $\mathrm{Q}=(1000 \times \mathrm{P} \times \mathrm{D})$ x $1.1(\mathrm{G} \mathrm{x} \mathrm{E})^{-1}$, where $\mathrm{P}=10.4 \mathrm{~g}$ (average mass of 100 seeds), $\mathrm{D}=14$ (number of plants per meter), $\mathrm{G}=80 \%$ (\% field emergence) and $\mathrm{E}=0.4 \mathrm{~m}$ (spacing) [19].

In the values estimated for insecticides were based on the average of $2.03 \mathrm{~L}$ determined by Roessing [17]. And for theherbicides, it was adopted the values used according to each treatment and for the grains, it was adopted according to the productivity of the experiments of the present study.

In the stage of energy inputs for industrial production, energy expenditures were calculated for conversion of the grain into oil and then the conversion of the oil into biodiesel, based on data from Pimentel and Patzek [14].

In order to calculate energy balance and energy efficiency, the Risoud methodology [16] was adopted in the following equations:

$\mathrm{BE}=\sum \mathrm{EBP}-\sum \mathrm{EENR}$

Where: BE: Energy Balance; EBP: Gross Energy from Products; EENR: Inputs from Non-Renewable Energies

$\mathrm{EFE}=\left(\sum \mathrm{EBP}\right) /\left(\sum \mathrm{EENR}\right)$

Where: EFE: Energy Efficiency; EBP: Gross Energy from Products; EENR: Inputs from Non-Renewable Energies

The total energy supplied by soybean was calculated from the sum of the energy equivalent to the product and its by-product resulting from the process. The main one is the oil, which is converted into biodiesel. The by-product is meal, which can be used in animal feed. It is considered that $1 \mathrm{~kg}$ soybean oil ha- ${ }^{-1}$ contains $9,000 \mathrm{kcal}$ energy and that every $1 \mathrm{~kg}$ meal ha ${ }^{-1}$ contains 4,000 kcal energy. On average, from every $1,000 \mathrm{~kg}$ soybeans, $180 \mathrm{~kg}$ oil and $820 \mathrm{~kg}$ meal are extracted [11].

\section{RESULTS AND DISCUSSION}

The energy consumed by the production system of a certain crop is not easy to determine, due to the factors that are involved, so it is necessary to estimate the energy consumed in the whole production process, which includes the activities of the production systems that need energy expenses, divided into stages, from pre-sowing, sowing, cultural management, harvesting and transportation. 
Figure 1 shows the oil balance (kcal), with the best results in treatments 3 (glyphosate + clethodim) and 4 (glyphosate + Cloransulam-Methyl) showing values of 577 and 781 (kcal ha $^{-1}$ ). Treatments 5 (glyphosate + Chlorimuron-Ethyl) and 6 (glyphosate + lactofen) showed a negative balance, due to the superiority of the total value of inputs (agricultural and industrial) in relation to the oil value.

\section{" Palotina Marechal Cândido Rondon}

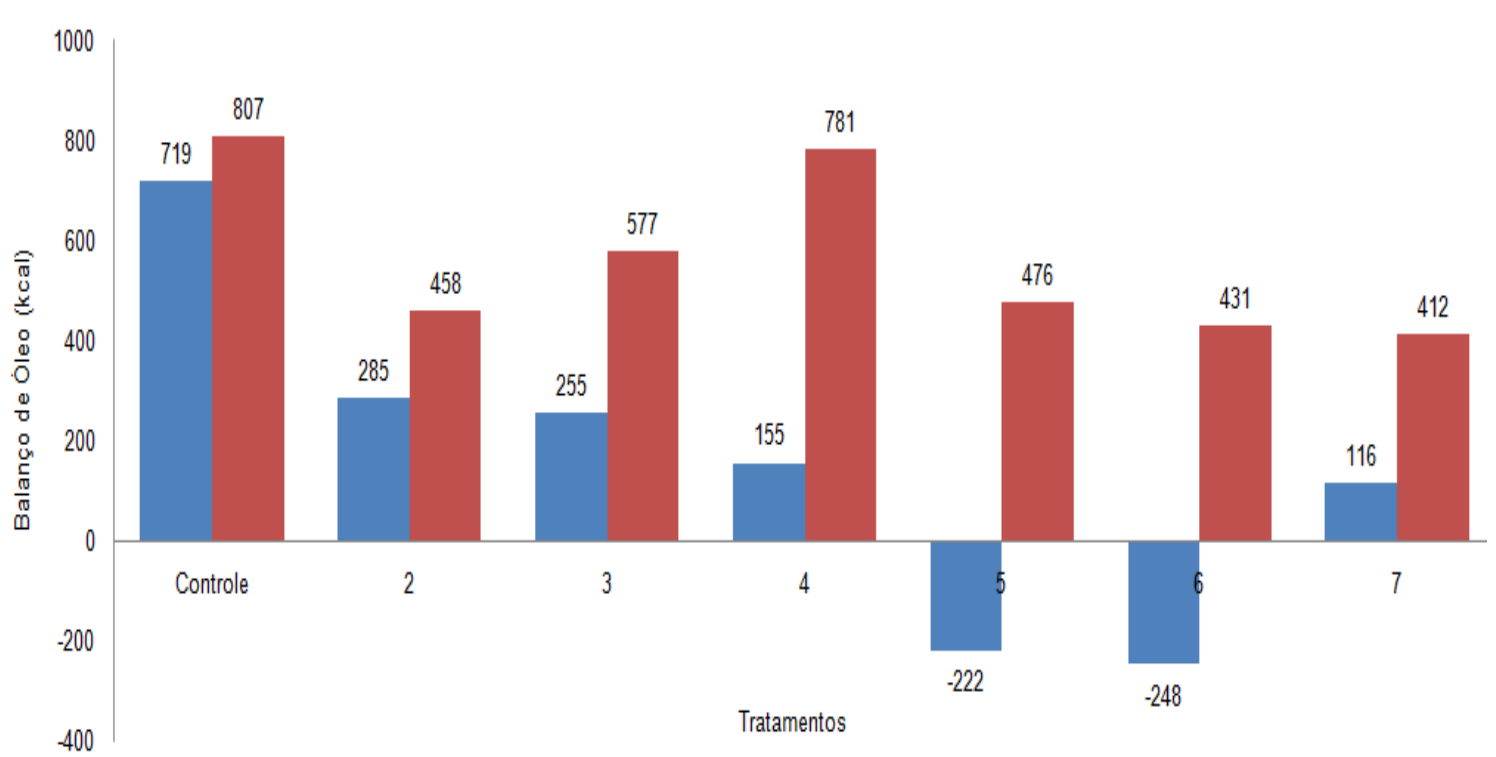

Figure 1- Oil balance (Kcal) of experiment 1 - glyphosate isolated and in combination.

Source: Authors based on the reference [1]

Figure 2 illustrates the oil balance $\left(\mathrm{kcal} \mathrm{ha}^{-1}\right)$ corresponding to experiment 2 . The treatments 2 (glyphosate at 720 ) yielded $547 \mathrm{kcal} \mathrm{ha}^{-1}$ and $462 \mathrm{kcal} \mathrm{ha}^{-1}$, presenting the best results, both with efficiency of 1: 1.11. It was found that for treatments 5,6 and 7 with doses of 2880, 3600 and 4320, the energy efficiencies were 1: 0.96; 1: 0.92 and 1: 0.88 , respectively. Thus, biodiesel production is impracticable, since energy efficiency proved to be negative for both municipalities. That is, each unit entering the system does not produce enough for one unit of energy. This because of the high doses of glyphosate, which were detrimental to productivity, consequently affecting the biodiesel production system.

Still in Figure 2, it is evident that the dose limit is between 720 and 2160 g e.a. ha ${ }^{-1}$. These results corroborate with Albrecht et al., [2], who showed that high doses of glyphosate in RR soybean had negative effects on yields, with a decrease of 0.40661 $\mathrm{kg} \mathrm{ha}^{-1}$ for each ge.a. applied per ha ${ }^{-1}$. 


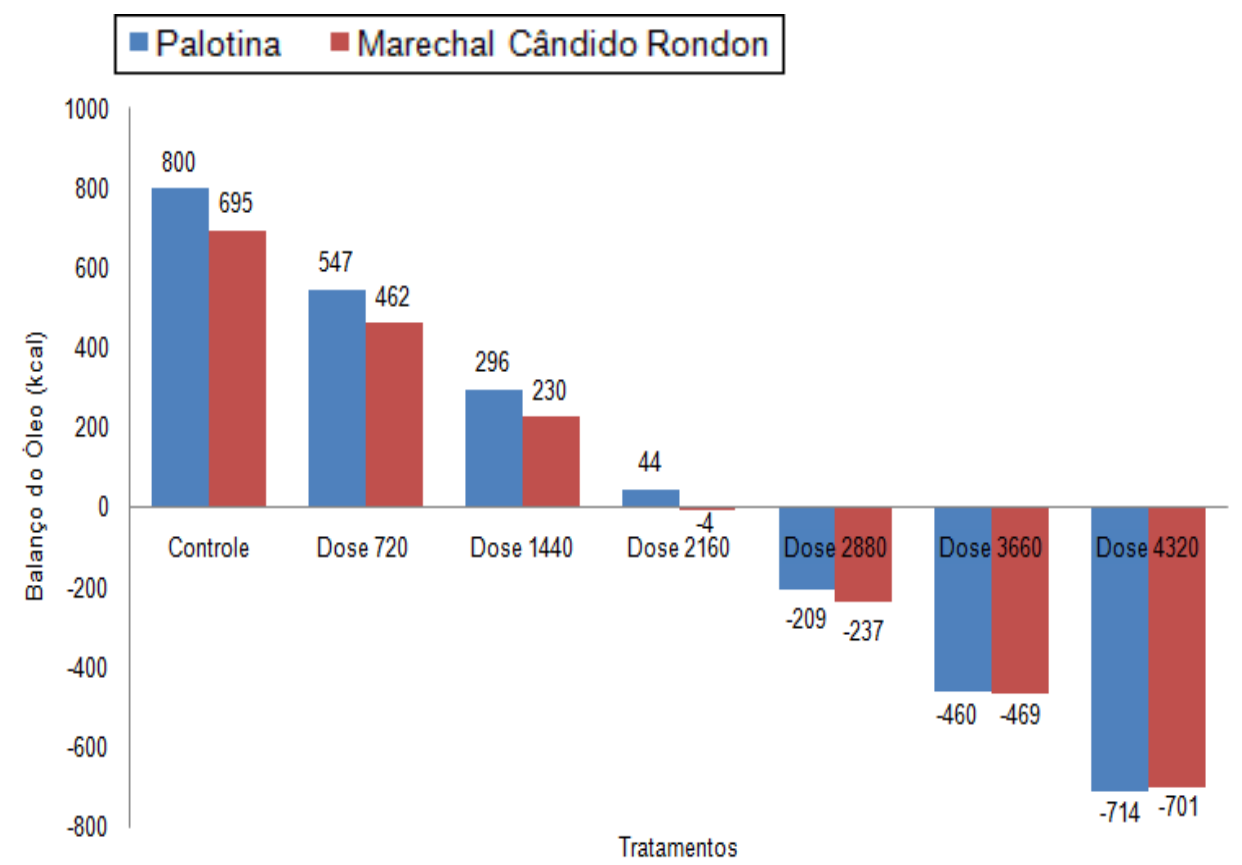

Figure 2 - Oil balance (Kcal) of experiment 2 - increasing doses of glyphosate. Source: Authors based on the reference [1]

In experiment 1 , the oil balance (kcal) showed the best results in treatments 3 (glyphosate + clethodim) and 4 (glyphosate + Cloransulam-Methyl), with values of 577 and $781\left(\mathrm{kcal} \mathrm{ha}^{-1}\right)$. The treatments 5 (glyphosate + Chlorimuron-Ethyl) and 6 (glyphosate + lactofen) presented a negative balance, due to the superiority of the total value of inputs (agricultural and industrial) in relation to the oil value, which corroborates with Delai [9] when assessing the energy and economic balance of soybeans for biodiesel production, which verified that the highest consumption for biodiesel production is observed in agricultural stages with a total of $76 \%$ and industrial energy consumption with a total of $21 \%$ consumption. Salla et al. [18] analyzed the energy balance of biofuel production from corn and reported that the costliest parameter of the total energy cost of agricultural production was registered in the inputs, and the total energy expenditure of operations in the industrial stages. Nevertheless, the performance of the analyzed crop in the energy balance aspect was positive, which improves its visibility and its potentiality.

Regarding experiment 2, treatments 2 (glyphosate at 720) yielded $547 \mathrm{kcal} \mathrm{ha}^{-1}$ and $462 \mathrm{kcal} \mathrm{ha}^{-1}$, presented the best results, both with an efficiency of 1: 1.11. For treatments 5, 6 and 7 at 2880, 3600 and 4320, the energy efficiencies were $1: 0.96 ; 1$ : 0.92 and 1: 0.88 , respectively, making the biodiesel production not feasible, since energy efficiency was negative for both municipalities. That is, each unit entering the system does not produce enough for one unit of energy. This is due to of the high doses of glyphosate, which were detrimental to productivity, consequently affecting the biodiesel production system. Still in Figure 2, it is evident that the dose limit is between 720 and $2160 \mathrm{~g}$ e.a. ha ${ }^{-1}$. These results corroborate with Albrecht et al., [2], who showed that high doses of glyphosate in RR soybean had negative effects on yields, with a decrease of $0.40661 \mathrm{~kg} \mathrm{ha}^{-1}$ for each ge.a. applied per ha-1.

Considering the purchase values of crude soybean oil, purchased directly from the producer, the cost varies from $\mathrm{R} \$ 1.70$ to $\mathrm{R} \$ 2.20$ per liter [9]. Portela [15] carried out a technical-economical study on biodiesel production in Brazil from soybean and castor bean. According to the author, the production of biodiesel is a viable alternative only if the economic, environmental and social motivations are equally considered, 
since none of them is strong enough to sustain the National Biodiesel Production and Use Program. Likewise, Araújo et al. al. [3] also conducted a technical and economic evaluation of biodiesel production from soybeans and castor bean in Brazil and state that the process is not feasible when extracted directly from soybean grains but economically viable when using oil extracted from soybean cake using extraction and transesterification, with the use of soybean protein as a co-product, due to the high value added to the grain, still being able to be added to the managements employed that hinder the development of the crop and consequently the final yield as treated in this work.

\section{CONCLUSION}

Considering the selectivity of herbicides, the best profitability was found in the treatments glyphosate + cloransulammethyl and glyphosate + clethodim. In relation to energy balance, treatments 5 (glyphosate + chlorimuronethyl) and 6 (glyphosate + lactofen) showed negative results for the oil balance (1:0.95).

The cultivar Intacta RR2 was sensitive to high doses of glyphosate, obtaining negative effects in development and thus impaired productivity, which consequently resulted in low economic returns, emphasizing, in experiment 2, the treatment 7 (glyphosate at 4320 g.e.a. ha ${ }^{-1}$ ), only $15.35 \%$ profitability and negative energy balance (1: 0.88$)$.

Experiments 1 and 2 showed favorable economic viability for the production of Intacta RR2 PROTM soybean, since their net margins were satisfactory; experiment 1 obtained better results for the municipality of Marechal Cândido Rondon, while experiment 2, for the municipality of Palotina. However, in the energetic issue, most treatments with high doses of herbicides did not show viability for biodiesel production, resulting in negative values, due to the high value invested along with the management that hindered the development of the soybean crop, thus making the use of soybean to produce biodiesel not feasible.

\section{REFERENCES}

1. Agência Nacional do Petróleo, Gás Natural E Biocombustíveis - Biodiesel Obrigatório 2014. Biocombustíveis. Disponível em: <http://www.anp.gov.br/?pg=73292\&m=\&t1=\&t2=\&t3=\&t4=\&ar=\&ps=\&1473681312205 $>$. Acesso em 11 de setembro de 2016.

2. Albrecht, LP et al. Desempenho da Soja Roundup Ready sob Aplicação de Glyphosate em Diferentes Estádios. Planta Daninha.v.29. n.3. p.585-590. Viçosa. Minas Gerais. 2011

3. Araújo, KM; Oliveira, AKC; Costa,GB; Queiroga, RNG.; Pannir, SPV .Estudo comparativo técnico e econômico de diferentes óleos vegetais brasileiros para produção de biocombustível. Natal: UFFRN, 2002.

4. Broch, DL, Ranno,SK. Fertilidade do Solo, Adubação e Nutrição da Cultura da Soja. Tecnologia e Produção: Soja e Milho 2011/2012. Fundação MS. 2012.

5. Carvalho, JLN.; Galdos, MV.; Cerri, CEP.; Feigl, BJ.; Bernoux, M; Cerri, CC. A soja e os novos desafios mundiais. In: Soja e Cia. Camara, GMS. Piracicaba. 2009. 334p.

6. Carvalho, L. - Economic Analysis Production Of Soybean Rr2 Pro And Soybean Rr1: A Case Study In Mato Grosso State. Botucatu, 2014. 55 F. Dissertação (Mestrado Em Agronomia / Energia Na Agricultura). Faculdade de Ciências Agronômicas. Universidade Estadual Paulista.

7. Cavalcante, AK. Determinação e avaliação do teor de óleo em sementes de soja pelos métodos de ressonância magnética nuclear e soxhlet. Biosciencejournal. V. 27, N.1. P. 8-15. Uberlândia. 2011

8. Comissão Técnica Nacional De Biossegurança- Ctnbio. Extrato De Parecer No 2542/2010. Brasília. Disponível Em: <Http://Www.Ctnbio.Gov.Br/Upd_Blob/0001/1400.Doc>. Acesso Em: Jul. De 2017 
9. Delai, MJ Avaliação Energética e Econômica da Obtenção de Biodiesel de Soja no Oeste do Paraná. Dissertação (Mestrado em Energia na Agricultura) - Setor de Energias Renováveis, Universidade Estadual do Oeste do Paraná, 2012.

10. Embrapa Soja- Agroenergia. 2016. Disponível Em:

<Http://Www.Agencia.Cnptia.Embrapa.Br/Gestor/Agroenergia/Arvore/Cont000fbl23vmz02w x5eo0sawqe3vtdl7vi.Html>. Acesso Em 05 de Agosto de 2017.

11. Gazzoni, D.L. et al. Balanço Energético das Culturas de Girassol e Soja para Produção de Biodiesel.Biomassa\&Energia.V.2, N.4, P. 259-265. Londrina. Paraná. 2005.

12. Gazzoni, D.L. et al. Balanço Energético da Cultura da Canola para a Produção de Biodiesel. Embrapa. Espaço Energia. No 11.2009.

13. Ipardes - Instituto Paranaense de Desenvolvimento Econômico e Social. Caderno Estatístico: Municípios . Paraná, 2016. Relatório Técnico.

14. Pimentel,D; Patzek, TW - Ethanol Production Using Corn, Switchgrass, and Wood; Biodiesel Production Using Soybean And Sunflower.International Association For Mathematical Geology. Natural Resources Research. V. 14. N. 1. 2005.

15. Portela, HE - Avaliação Técnico-Econômica de um Empreendimento Produtivo de Biodiesel. 2007. Dissertação (Mestrado) - Universidade Federal da Bahia, Escola Politécnica, Salvador, BA.

16. Risoud,B. - Développementdurableetanalyseenergétiqued' Exploitations agricoles. Économierurale, N.252, P.16-27. 1999.

17. Roessing, AC - Consumo De Energia Na Produção De Soja. Congresso Brasileiro de Energia. Anais. V. 2. P. 561-572. Universidade Federal do Rio de Janeiro. Rio de Janeiro. 2006.

18. Salla, DA. Estudo Energético Da Produção De Biocombustível a Partir do Milho.Ciência Rural. V.40. N.9. P.2017-2022. Issn 0103-8478. Santa Maria. Rio Grande do Sul. ,2010.

19. Silveira, J. M . Semeadura e Manejo da Cultura de Girassol. Girassol no Brasil. Embrapa Soja. Londrina. Paraná. P. 381. 2005. 